\title{
STOCHASTIC LEONTIEFF-TYPE EQUATIONS WITH MULTIPLICATIVE EFFECT IN SPACES OF COMPLEX-VALUED "NOISES"
}

\author{
A. L. Shestakov, South Ural State University, Chelyabinsk, Russian Federation, \\ admin@susu.ac.ru, \\ M. A. Sagadeeva, South Ural State University, Chelyabinsk, Russian Federation, \\ sam79@74.ru
}

We consider a Leontieff-type stochastic equation, that is, a system of differential equations implicit with respect to the time derivative in the spaces of random processes. The concepts previously introduced for the spaces of differentiable "noise" using the NelsonGliklikh derivative carry over to the case of complex-valued "noise"; in addition, the right-hand side of the equation is subject to multiplicative effect of a special form. We construct a solution to the Showalter-Sidorov problem for Leontieff-type equations with multiplicative effect of a complex-valued process of special form. Aside from the introduction and references, the article consists of two parts. In the first part we carry over various concepts of the space of real-valued differentiable "noise" to the complex-valued case. In the second part we construct a Showalter-Sidorov solution to a Leontieff-type equation with multiplicative effect of a complex-valued process of special form. The list of references is not intended to be complete and reflects only the authors' personal preferences.

Keywords: Leontieff-type equations; multiplicative effect; Wiener process; NelsonGliklikh derivative; space of complex-valued "noises"; "white noise".

\section{Introduction}

In the spaces of random processes, consider the stochastic equation

$$
L \stackrel{\circ}{\xi}(t)=e^{i \alpha t} M \xi(t)+N \stackrel{\circ}{W}_{k}(t), \quad \operatorname{ker} L \neq\{0\},
$$

where $\alpha$ is a real-valued Gaussian random variable, $L, M$, and $N$ are matrices of complex coefficients, $\xi(t)$ is the required complex-valued random process with the Nelson-Gliklikh derivative $\stackrel{\circ}{\xi}$, and $W_{k}(t)$ is the $k$-Wiener process.

Ito pioneered the study of linear ordinary stochastic differential equations, and later Stratonovich and Skorokhod joined in. The approach of Ito-Stratonovich-Skorokhod is still popular [1, 2] in the finite-dimensional case. Moreover, it was successfully extended to an infinite-dimensional situation [3] and even to Sobolev-type equations [4, 5, 6]. The right-hand side involved the differential of a Wiener processes, whose generalized derivative is traditionally treated as white noise. Let us also mention the approach of Mel'nikova's school [7], in which ordinary stochastic differential equations are considered in Schwartz spaces, where the generalized derivative of a Wiener process makes sense.

A new approach in stochastic ordinary differential equations arose [8] and is actively developing [9], in which "white noise" is regarded as the Nelson-Gliklikh derivative of a Wiener processes. This "white noise" is more adequate for the Einstein-Smoluchowski theory of Brownian motion than the traditional white noise [8, 9]. Originally "white noise" 
was used in the theory of optimal measurements [10,11], which required constructing a special space of real-valued "noises" [9]. In this article for the finite-dimensional case we carry over the concepts and results of $[6,9]$ to complex-valued random processes. In these spaces we construct a solution to a Leontieff-type equation (1) with multiplicative effect of a complex-valued process of special form basing on the deterministic case [11, 12].

\section{Spaces of Complex-Valued "Noises"}

Take a complete probability space $\Omega \equiv(\Omega, \mathcal{A}, \mathbf{P})$ and the set $\mathbb{C}$ of complex numbers equipped with the structure of a Borel $\sigma$-algebra. A measurable mapping $\xi: \Omega \rightarrow \mathbb{C}$ is called a random variable. The set of random variables constitutes a Hilbert space with the inner product $\left(\xi_{1}, \xi_{2}\right)=\mathbf{E} \xi_{1} \overline{\xi_{2}}$. Denote this Hilbert space by $\mathbf{L}_{\mathbf{2}}$. Below the random variables $\xi \in \mathbf{L}_{2}$ with the normal (Gaussian) distribution are important, and we refer to them as Gaussian variables.

Consider now a $\sigma$-subalgebra $\mathcal{A}_{0}$ of the $\sigma$-algebra $\mathcal{A}$. Construct the space $\mathbf{L}_{2}^{0}$ of random variables which are measurable with respect to $\mathcal{A}_{0}$. It turns out that $\mathbf{L}_{2}^{0}$ is a subspace of $\mathbf{L}_{\mathbf{2}}$, Denote by $\Pi: \mathbf{L}_{\mathbf{2}} \rightarrow \mathbf{L}_{\mathbf{2}}^{\mathbf{0}}$ the corresponding orthogonal projection. For $\xi \in \mathbf{L}_{\mathbf{2}}$ refer to $\Pi \xi$ as the conditional expectation of the random variable $\xi$ and denote it by $\mathbf{E}\left(\xi \mid \mathcal{A}_{0}\right)$. It is not difficult to observe that $\mathbf{E}\left(\xi \mid \mathcal{A}_{0}\right)=\mathbf{E} \xi$ for $\mathcal{A}_{0}=\{\emptyset, \Omega\}$ and $\mathbf{E}\left(\xi \mid \mathcal{A}_{0}\right)=\xi$ for $\mathcal{A}_{0}=\mathcal{A}$. Finally, recall that the minimal $\sigma$-subalgebra $\mathcal{A}_{0} \subset \mathcal{A}$ with respect to which a random variable $\xi$ is measurable is called the $\sigma$-algebra generated by $\xi$.

Consider now some interval $\mathfrak{I} \subset \mathbb{R}$ and two mappings. The first mapping $f: \mathfrak{I} \rightarrow \mathbf{L}_{\mathbf{2}}$ associates to each $t \in \mathfrak{I}$ a random variable $\xi \in \mathbf{L}_{\mathbf{2}}$. The second mapping $g: \mathbf{L}_{\mathbf{2}} \times \Omega \rightarrow \mathbb{C}$ associates to each pair $(\xi, \omega)$ a point $\xi(\omega) \in \mathbb{C}$. Refer to a mapping $\eta: \mathfrak{I} \times \Omega \rightarrow \mathbb{C}$ defined as $\eta=\eta(t, \omega)=g(f(t), \omega)$ as a (one-dimensional) complex-valued random process. Therefore, for each fixed $t \in \mathfrak{I}$ the random process $\eta=\eta(t, \cdot)$ is a complex random variable, that is, $\eta(t, \cdot) \in \mathbf{L}_{\mathbf{2}}$, while for each fixed $\omega \in \Omega$ the random process $\eta=\eta(\cdot, \omega)$ is called a (choice of) trajectory. A random process $\eta$ is called continuous whenever almost surely all its trajectories are continuous (that is, for almost all $\omega \in \Omega$ the trajectories $\eta(\cdot, \omega)$ are continuous). The set of continuous random processes constitutes a Banach space, which we denote by $\mathbf{C}(\mathfrak{I} ; \mathbb{C})$. A continuous random process with (independent) Gaussian random variables is called a Gaussian process.

The most important example of a continuous complex-valued Gaussian random process is the (one-dimensional) Wiener process $\beta=\beta(t)$ modeling the Brownian motion on a complex plane in the Einstein-Smoluchowski theory. It enjoys the following properties:

(W1) almost surely $\beta(0)=0$, almost surely all its trajectories $\beta(t)$ are continuous, and for all $t \in \overline{\mathbb{R}}_{+}(=\{0\} \cup \mathbb{R})$ the random variable $\beta(t)$ is Gaussian;

(W2) the expectation is $\mathbf{E}(\beta(t))=0$ and the autocorrelation function is $\mathbf{E}\left(|\beta(t)-\beta(s)|^{2}\right)=|t-s|$ for all $s, t \in \overline{\mathbb{R}}_{+}$.

Remark 1. For the process with properties (W1), (W2) also satirsfire

(W3) the trajectories $\beta(t)$ are nondifferentiable at every point $t \in \overline{\mathbb{R}}_{+}$and of unbounded variation on every arbitrarily small interval.

A random process $\beta$ with properties (W1)-(W3) is called Brownian motion.

Fixing $\eta \in \mathbf{C}(\mathfrak{I} ; \mathbb{C})$ and $t \in \mathfrak{I}(=(\varepsilon, \tau) \subset \mathbb{R})$, denote by $\mathcal{N}_{t}^{\eta}$ the $\sigma$-algebra generated by the random variable $\eta(t)$. Put $\mathbf{E}_{t}^{\eta}=\mathbf{E}\left(\cdot \mid \mathcal{N}_{t}^{\eta}\right)$ for brevity. 
Definition 1. On assuming that $\eta \in \mathbf{C}(\varepsilon, \tau ; \mathbb{C})$, refer as the (right left) derivative in the mean $D \eta(t, \cdot)\left(D_{*} \eta(t, \cdot)\right)$ of the random process $\eta$ at $t \in(\varepsilon, \tau)$ to the random variable

$$
D \eta(t, \cdot)=\lim _{\triangle t \rightarrow 0+} E_{t}^{\eta}\left(\frac{\eta(t+\triangle t, \cdot)-\eta(t, \cdot)}{\triangle t}\right) \quad\left(D_{*} \eta(t, \cdot)=\lim _{\triangle t \rightarrow 0+} E_{t}^{\eta}\left(\frac{\eta(t, \cdot)-\eta(t-\triangle t, \cdot)}{\triangle t}\right)\right)
$$

whenever the limit exists in the sense of uniform metric on $\mathbb{R}$. A random process $\eta$ is called (right left) differentiable in the mean on $(\varepsilon, \tau)$ whenever at each point $t \in(\varepsilon, \tau)$ its right (left) derivative in the mean exists.

Therefore, take a random process $\eta \in \mathbf{C}(\varepsilon, \tau ; \mathbb{C})$ which is right (left) differentiable in the mean on $(\varepsilon, \tau)$. Its right (left) derivative in the mean is a random process as well, which we denote by $D \eta\left(D_{*} \eta\right)$. If $\eta \in \mathbf{C}(\varepsilon, \tau ; \mathbb{C})$ is both right and left differentiable in the mean on $(\varepsilon, \tau)$ then we can define the symmetric (antisymmetric) derivative in the mean $D_{S} \eta=\frac{1}{2}\left(D+D_{*}\right) \eta\left(D_{A} \eta=\frac{1}{2}\left(D_{*}-D\right) \eta\right)$. Since Nelson introduced derivatives in the mean [13] and Gliklikh developed their theory [2], for brevity we call the symmetric derivative in the mean $D_{S}$ of a random process $\eta$ the Nelson-Gliklikh derivative and denote it by $\stackrel{\circ}{\eta}$, that is, put $D_{S} \eta \equiv \stackrel{\circ}{\eta}$. For $\ell \in \mathbb{N}$, denote by $\stackrel{\circ}{\eta}^{(\ell)}$ the order $\ell$ NelsonGliklikh derivative of $\eta$. Observe that if the trajectories of $\eta$ are almost surely continuously differentiable in the ordinary sense on $(\varepsilon, \tau)$ then their Nelson-Gliklikh derivative coincides with the ordinary derivative. For instance, this is so for the random real-valued process $\eta=\alpha \sin (\nu t)$, where $\alpha$ is a Gaussian random real-variable and $\nu \in \mathbb{R}_{+}$is a fixed constant, while $t \in \mathbb{R}$ has the meaning of time.

Theorem 1. (Gliklikh) We have $\stackrel{\circ}{\eta}^{(\ell)}(t)=(-1)^{\ell+1}(2 t)^{-\ell} \eta(t)$ for all $t \in \mathbb{R}_{+}$and $\ell \in \mathbb{N}$.

Consider the space $\mathbf{C}^{\ell}(\mathfrak{I} ; \mathbb{C})$, with $\ell \in \mathbb{N}$, of random process in $\mathbf{C}(\mathfrak{I} ; \mathbb{C})$ whose trajectories are almost surely Nelson-Gliklikh differentiable on $\mathfrak{I}$ through order $\ell$. If $\mathfrak{I} \subset \mathbb{R}_{+}$

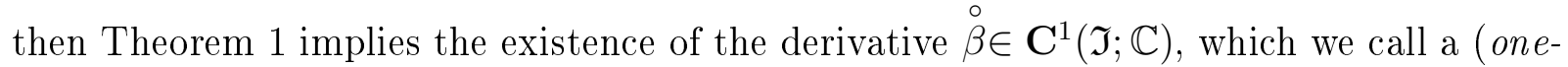
dimensional) "white noise". In [9] the spaces $\mathbf{C}^{1}(\mathfrak{I} ; \mathbb{C})$ are called the spaces of differentiable "noises".

Fixing now $k \in \mathbb{N}$, take $k$ independent random processes $\left\{\eta_{1}(t), \eta_{2}(t), \ldots, \eta_{k}(t)\right\}$ and define the $k$-dimensional random process (or briefly, a $k$-random process) as $\Theta(t)=$ $\sum_{j=1}^{k} \eta_{j}(t) e_{j}$, where $e_{j}$ for $j=\overline{1, k}$ are the standard basis vectors in $\mathbb{C}^{k}$. It is obvious that almost surely all its trajectories are continuous whenever $\eta_{j} \in \mathbf{C}(\mathfrak{I} ; \mathbb{C})$ for $j=\overline{1, k}$ and Nelson-Gliklikh continuously differentiable through order $\ell$ whenever $\eta_{j} \in \mathbf{C}^{\ell}(\mathfrak{I} ; \mathbb{C})$ for $j=\overline{1, k}$. By analogy with the above, introduce the spaces $\mathbf{C}\left(\mathfrak{I} ; \mathbb{C}^{k}\right)$ and $\mathbf{C}^{\ell}\left(\mathfrak{I} ; \mathbb{C}^{k}\right)$ of continuous and continuously differentiable $k$-dimensional "noises". As an example, consider the $k$-dimensional Wiener process ( $k$-Wiener process)

$$
W_{k}(t)=\sum_{j=1}^{k} \beta_{j}(t) e_{j}
$$

where $\beta_{j}$ for $j=\overline{1, k}$ are independent Brownian motions. Theorem 1 yields

It follows from (2) that the $k$-Wiener process $W_{k}$ enjoys properties (W1)-(W3) with $\beta$ replaced by $W_{k}$. On assuming this replacement made, we have 
Theorem 2. For each $k \in \mathbb{N}$ with probability 1 there exists a unique $k$-Wiener process $W_{k}$ with properties (W1)-(W3); furthermore, we can express it as (2).

\section{Stochastic Leontieff-Type Equations with Multiplicative Effect}

Take two square matrices $L$ and $M$ of size $k$ with complex entries. Following [6] and [10], refer to the sets $\rho^{L}(M)=\{\mu \in \mathbb{C}: \operatorname{det}(\mu L-M) \neq 0\}$ and $\sigma^{L}(M)=\mathbb{C} \backslash \rho^{L}(M)$ respectively as the $L$-resolvent set and $L$-spectrum of $M$. It is not difficult to show that either $\rho^{L}(M)=\emptyset$ or the $L$-spectrum of $M$ amounts to a finite set of points. In addition, observe that $\rho^{L}(M)$ and $\sigma^{L}(M)$ are preserved under the changes of basis. Define also the matrix-valued functions $(\mu L-M)^{-1}, R_{\mu}^{L}(M)=(\mu L-M)^{-1} L$, and $L_{\mu}^{L}(M)=L(\mu L-M)^{-1}$ on $\rho^{L}(M)$ and call them respectively the L-resolvent, the right and left L-resolvents of $M$.

Definition 2. For $p \in\{0\} \cup \mathbb{N}$, call $M$ an $(L, p)$-regular matrix whenever $\rho^{L}(M) \neq \emptyset$ and $\infty$ is either a removable singular point (for $p=0$ ) or a pole of order $p \in \mathbb{N}$ of the $L$-resolution of $M$.

Take an $(L, p)$-regular matrix $M$ with $p \in\{0\} \cup \mathbb{N}$. Consider the system of Leontiefftype equations

$$
L \stackrel{\circ}{\xi}(t)=e^{i \alpha t} M \xi(t)+N w(t), \quad \operatorname{ker} L \neq\{0\},
$$

where $\alpha$ is a real-valued Gaussian random variable, $\xi(t)$ is the required random process with the Nelson-Gliklikh derivative $\stackrel{\circ}{\xi}$, and $w=w(t)$ is a random process corresponding to the outside effect.

Impose for (3) the Showalter-Sidorov initial condition

$$
\left[R_{\nu}^{L}(M)\right]^{p+1}\left(\xi(0)-\xi_{0}\right)=0, \quad \nu \in \rho^{L}(M) .
$$

Observe that for the Leontieff-type system [10] this condition is more natural than the traditional Cauchy condition $\xi(0)=\xi_{0}$.

Take now $\mathfrak{I}=[0, \tau)$. Call a random process $\xi \in \mathbf{C}^{1}\left(0, \tau ; \mathbb{C}^{k}\right)$ a $($ classical $)$ solution to (3) whenever almost surely all its trajectories satisfy (3) for some random process $w \in \mathbf{C}\left(0, \tau ; \mathbb{C}^{k}\right)$, a complex matrix $N$ of size $k$, and all $t \in(0, \tau)$. Call a solution $\xi=\xi(t)$ to (3) a (classical) solution to problem (3), (4) whenever condition (4) holds as well.

Theorem 3. Take an (L,p)-regular matrix $M$ for $p \in\{0\} \cup \mathbb{N}$ with $\operatorname{det} M \neq 0$. Given a matrix $N: \mathbb{C}^{k} \rightarrow \mathbb{C}^{k}$, a random process $w=w(t)$ with

$$
(\mathbb{I}-Q) N w \in \mathbf{C}^{p+1}\left(\mathfrak{I} ; \mathbb{C}^{k}\right) \quad \text { and } \quad Q N w \in \mathbf{C}\left(\mathfrak{I} ; \mathbb{C}^{k}\right),
$$

and a random variable $\xi_{0} \in \mathbf{L}_{2}$ independent of $w$, there exists a unique solution $\xi \in$ $\mathbf{C}^{1}\left(\mathfrak{I} ; \mathbb{C}^{k}\right)$ to problem $(3)$, (4) of the form

$$
\begin{gathered}
\xi(t)=\lim _{n \rightarrow \infty}\left[\left(\left(L+\frac{i}{n \alpha} M\left(e^{i \alpha t}-1\right)\right)^{-1} L\right)^{n} \xi_{0}+\right. \\
+\int_{0}^{t}\left(\left(L+\frac{i}{n \alpha} M\left(e^{i \alpha t}-e^{i \alpha s}\right)\right)^{-1} L\right)^{n}\left(L-\frac{1}{n} M\right)^{-1}\left(n L_{n}^{L}(M)\right)^{p} N w(s) d s+
\end{gathered}
$$




$$
\left.+\sum_{q=0}^{p}\left(M^{-1}\left(\mathbb{I}_{k}-\left(n L_{n}^{L}(M)\right)^{p+1}\right) L\right)^{q} M^{-1}\left(\left(n L_{n}^{L}(M)\right)^{p+1}-\mathbb{I}_{k}\right)\left(e^{-i \alpha t} D_{S}\right)^{q}\left(e^{-i \alpha t} N w(t)\right)\right] .
$$

Proof of this theorem repeats almost verbatim the arguments of [11, 12], taking into account the features of the space of "noises" [6,9], and is therefore omitted.

However, the "white noise" $w(t)=\stackrel{\circ}{W}_{k}(t)=(2 t)^{-1} W_{k}(t)$ doesn't satisfy (5) and we can't substitute it into (3) and (4). So for equation (1) we consider the weakened ShowalterSidorov initial condition

$$
\lim _{t \rightarrow 0+}\left[R_{\nu}^{L}(M)\right]^{p+1}\left(\xi(t)-\xi_{0}\right)=0, \quad \nu \in \rho^{L}(M) .
$$

Using the results from [6] and Theorem 3, we obtain next

Corollary 1. Take an $(L, p)$-regular matrix $M$ for $p \in\{0\} \cup \mathbb{N}$ with $\operatorname{det} M \neq 0$. Given a matrix $N: \mathbb{C}^{k} \rightarrow \mathbb{C}^{k}$ and a random variable $\xi_{0} \in \mathbf{L}_{2}$ independent of $k$-Wiener process $W_{k}$, there exists a unique solution $\xi \in \mathbf{C}^{1}\left(\mathfrak{I} ; \mathbb{C}^{k}\right)$ to problem (1), (6) of the form

$$
\begin{aligned}
& \xi(t)=\lim _{n \rightarrow \infty}\left[\left(\left(L+\frac{i}{n \alpha} M\left(e^{i \alpha t}-1\right)\right)^{-1} L\right)^{n} \xi_{0}+\left(L-\frac{1}{n} M\right)^{-1}\left[\left(n L_{n}^{L}(M)\right)^{p} N W_{k}(t)-\right.\right. \\
& \left.-M \int_{0}^{t}\left(\left(L+\frac{i}{n \alpha} M\left(e^{i \alpha t}-e^{i \alpha s}\right)\right)^{-1} L\right)^{n}\left(L-\frac{1}{n} M\right)^{-1}\left(n L_{n}^{L}(M)\right)^{p} N W_{k}(s) d s\right]+ \\
& \left.+\sum_{q=0}^{p}\left(M^{-1}\left(\mathbb{I}_{k}-\left(n L_{n}^{L}(M)\right)^{p+1}\right) L\right)^{q} M^{-1}\left(\left(n L_{n}^{L}(M)\right)^{p+1}-\mathbb{I}_{k}\right)\left(e^{-i \alpha t} D_{S}\right)^{q}\left(e^{-i \alpha t} N W_{k}(t)\right)\right] .
\end{aligned}
$$

\section{References}

1. Arato M. Linear Stochastic Systems with Constant Coefficients. A Statistical Approach. Berlin, Heidelberg, N.-Y., Springer, 1982. DOI: 10.1007/BFb0043631

2. Gliklikh Yu.E. Global and Stochastic Analysis with Applications to Mathematical Physics. London, Dordrecht, Heidelberg, N.-Y., Springer, 2011. DOI: $10.1007 / 978-0-85729-163-9$

3. Da Prato G., Zabczyk J. Stochastic Equations in Infinite Dimensions. Cambridge, Cambridge University Press, 1992. DOI: 10.1017/CBO9780511666223

4. Zamyshlyaeva A.A. Stochastic Mathematical Model of Ion-Acoustic Waves in Plasma. Estestvennye $i$ Tekhnicheskie nauki [Natural and Technical Sciences], 2013, no. 4, pp. 284-292. (in Russian)

5. Zagrebina S.A., Soldatova E.A. The linear Sobolev-type Equations With Relatively pbounded Operators and Additive White Noise. Izvestija Irkutskogo gosudarstvennogo universiteta. Seriya "Matematika" [News of Irkutsk State University. Series "Mathematics"], 2013, vol. 6, no. 1, pp. 20-34. (in Russian) 
6. Sviridyuk G.A., Manakova N.A. The Dynamical Models of Sobolev Type with Showalter - Sidorov Condition and Additive "Noise". Bulletin of the South Ural State University. Series "Mathematical Modelling, Programming \& Computer Software", 2014, vol. 7, no. 1, pp. 90-103. (in Russian) DOI: 10.14529/mmp140108

7. Melnikova I.V., Filinkov A.I., Alshansky M.A. Abstract Stochastic Equations II. Solutions in Spaces of Abstract Stochastic Distributions. J. of Mathematical Sciences, 2003, vol. 116, no. 5, pp. 3620-3656. DOI: 10.1023/A:1024159908410

8. Shestakov A.L., Sviridyuk G.A. On a New Conception of White Noise. Obozrenie Prikladnoy i Promyshlennoy Matematiki, 2012, vol. 19, issue 2, pp. 287-288. (in Russian)

9. Shestakov A.L., Sviridyuk G.A., Hudyakov Yu.V. Dinamic Measurement in Spaces of "Noise". Bulletin of the South Ural State University. Series "Computer Technologies, Automatic Control, Radio Electronics", 2013, vol. 13, no. 2, pp. 4-11. (in Russian)

10. Shestakov A.L., Keller A.V., Nazarova E.I. Numerical Solution of the Optimal Measurement Problem. Automation and Remote Control, 2012, vol.73, no. 1, pp. 97-104. DOI: $10.1134 /$ S0005117912010079

11. Shestakov A., Sviridyuk G., Sagadeeva M. Reconstruction of a Dynamically Distorted Signal with Respect to the Measuring Transducer Degradation. Applied Mathematical Sciences, 2014, vol. 8, no. 41-44, pp. 2125-2130. DOI: 10.12988/ams.2014.312718

12. Keller A.V., Sagadeeva M.A. The Numerical Solution of Optimal and Hard Control for Nonstationary System of Leontiev type. Nauchnye vedomosti Belgorodskogo gosudarstvennogo universiteta. Seriya: Matematika. Fizika, 2013, vol. 32, no. 19, pp. 57-66. (in Russian)

13. Nelson E. Dynamical Theories of Brownian Motion. Princeton, Princeton University Press, 1967.

Received September 9, 2014

УДК 517.9

DOI: $10.14529 / \mathrm{mmp} 140412$

\section{СТОХАСТИЧЕСКИЕ УРАВНЕНИЯ ЛЕОНТЬЕВСКОГО ТИПА С МУЛЬТИПЛИКАТИВНЫМ ВОЗДЕЙСТВИЕМ В ПРОСТРАНСТВАХ КОМПЛЕКСНОЗНАЧНЫХ «ШУМОВ»}

\section{А.Л. Шестаков, М.А. Сагадеева}

В статье рассматривается стохастическое уравнение леонтьевского типа, т.е. система дифференциальных уравнений, неразрешенная относительно производной по времени, в пространствах случайных процессов. При этом введенные ранее с помощью производной Нельсона-Гликлиха понятия для пространств дифференцируемых «шумов», переносятся на случай комплекснозначных «шумов», и, кроме того, в уравнении присутствует мультипликативное воздействие специального вида на правую часть уравнения. В статье строится решение задачи Шоуолтера-Сидорова для уравнения леонтьевского типа с мультипликативным воздействием комплекснозначного процесса специального вида. 
Статья кроме введения и списка литературы содержит две части. В первой из них производится перенос понятий пространства дифференцируемых «шумов» с действительнозначного случая на комплекснозначный, а во второй - строится решение Шоуолтера-Сидорова для уравнения леонтьевского типа с мультипликативным воздействием комплекснозначного процесса специального вида. Список литературы не претендует на полноту, и отражает лишь личные пристрастия авторов.

Ключевые слова: уравнение леоньевского типа; мультипликативное воздействие; винеровский процесс; производнал Нельсона - Гликлиха; пространство комплекснозначных «иумов»; «белый шум».

\section{Литература}

1. Arato, M. Linear Stochastic Systems with Constant Coefficients. A Statistical Approach / M. Arato. - Berlin; Heidelberg; N.-Y.: Springer, 1982.

2. Gliklikh, Yu.E. Global and Stochastic Analysis with Applications to Mathematical Physics / Yu.E. Gliklikh. - London; Dordrecht; Heidelberg; N.-Y.: Springer, 2011.

3. Da Prato, G. Stochastic Equations in Infinite Dimensions / G. Da Prato, J. Zabczyk. - Cambridge: Cambridge University Press, 1992.

4. Замышляева, А.А. Стохастическая математическая модель ионно-звуковых волн в плазме / А.А. Замышляева // Естественные и технические науки. - 2013. - № 4. - C. 284-292.

5. Загребина, С.А. Линейные уравнения соболевского типа с относительно рограниченными операторами и аддитивным белым шумом / С.А. Загребина, Е.А. Солдатова // Известия Иркутского государственного университета. Серия: Математика. - 2013. - № 1. - С. 20-34.

6. Свиридюк, Г.А. Динамические модели соболевского типа с условием Шоуолтера Сидорова и аддитивными «шумами»/ Г.А. Свиридюк, Н.А. Манакова // Вестник ЮУрГУ. Серия: Математическое моделирование и программирование. - 2014. T. 7, № 1. - C. 90-103.

7. Melnikova, I.V. Abstract Stochastic Equations II. Solutions in Spaces of Abstract Stochastic Distributions / I.V. Melnikova, A.I. Filinkov, M.A. Alshansky // J. of Mathematical Sciences. - 2003. - V. 116, № 5. - P. 3620-3656.

8. Шестаков, А.Л. О новой концепции белого шума / А.Л. Шестаков, Г.А. Свиридюк // Обозрение прикладной и промышленной математики. - 2012. - Т. 19, № 2. - C. 287.

9. Шестаков, А.Л. Динамические измерения в пространствах "шумов" / А.Л. Шестаков, Г.А. Свиридюк, Ю.В. Худяков // Вестник ЮУрГУ. Серия: Компьютерные технологии, управление, радиоэлектроника. - 2013. - Т. 13, № 2. - С. 4-11.

10. Шестаков, А.Л. Численное решение задачи оптимального измерения / А.Л. Шестаков, А.В. Келлер, Е.И. Назарова // Автоматика и телемеханика. - 2012. - № 1. - C. $107-115$.

11. Shestakov, A. Reconstruction of a Dynamically Distorted Signal with Respect to the Measuring Transducer Degradation / A. Shestakov, G. Sviridyuk, M. Sagadeeva // Applied Mathematical Sciences. - 2014. - V. 8, № 41-44. - P. 2125-2130. 
12. Келлер, А.В. Численное решение задач оптимального и жесткого управления для одной нестационарной системы леонтьевского типа / А.В. Келлер, М.А. Сагадеева // Научные ведомости Белгородского государственного университета. Серия: Математика. Физика. - 2013. - Т. 32, № 19 (162). - С. 57-66.

13. Nelson, E. Dynamical Theories of Brownian Motion / E. Nelson. - Princeton: Princeton University Press, 1967.

Александр Леонидович Шестаков, доктор технических наук, профессор, кафедра «Информационно-измерительная техника», Южно-Уральский государственный университет (г. Челябинск, Российская Федерация), admin@susu.ac.ru

Минзиля Алмасовна Сагадеева, кандидат физико-математических наук, доцент, кафедра «Математическое моделирование», Южно-Уральский государственный университет (г. Челябинск, Российская Федерация), sam79@74.ru

Поступила в редакцию 9 сентлбря 2014 г. 